\title{
Activin a and follistatin in chronic heart failure
}

\author{
Howaida Nounou; Azza Hassan*; Hanan K.AbdelAziz. \\ Department of Biochemistry and Internal Medicine* \\ Faculty of Medicine, Alexandria University, Egypt
}

\begin{abstract}
Activin A a member of TGF-B superfamily has been involved in several pathologic processes. It is also accused to have a pathognomonic role in atherogenesis and the development of heart failure. Its activity is regulated by a glycoprotein called follistatin that bind activin preventing its function. $u P A$ is a serine protease that activates plasminogen thus initiating a cascade of fibrinolysis and extra cellular proteolysis. The aim of this study is to assess the role of activin A, follistatin and uPA in patients with chronic heart failure and to find if there is any correlation among their levels. The present study was conducted on 30 patients with chronic heart failure as a result of cardiomyopathy or ischemic heart diseases (group I). There were 20 healthy subjects of matched age and sex involved in the study as a control group (group II). In both groups serum activin A, follistatin, UPA and lipid profile that included serum T.G, total cholesterol, LDLc and HDLc were estimated. Results: there was a significant increase in serum activin A and follistatin and a significant decrease of UPA in group I as compared to controls. As regard to lipid profile there was a significant increase in serum T.G, serum total cholesterol and serum LDLc in group I than group II while there was a significant decrease in patients than the controls regarding HDLc. There was significant positive correlation between activin $A$ and urokinase plasminogen activator ( $U P A)$ in group 1. Conclusion: activin A/follistatin system may play a role in the pathogenesis of heart failure; also uPA could be suggested to have an important role in atherosclerosis and ischemic vascular disease that predisposes to heart failure due to the possible role of activin $A$ cytokine in the fibrinolytic activity of $U P A$.
\end{abstract}

\section{INTRODUCTION}

Activins are members of the TGF- $\beta$ superfamily. They are dimeric proteins composed of two $\beta$ subunits, which are linked by a single covalent disulfide bond; allowing for the formation of three forms of activin: A, $\mathrm{AB}$, and $\mathrm{B}^{(\mathbf{1})}$, Activin signaling is mediated by cell- surface type I and type II activin receptors. ${ }^{(2)}$

Activin A, a homodimer of activin $\beta_{\mathrm{A}}$ subunits, although originally described as an inducer of a follicle- stimulating hormone release, activin $\mathrm{A}$ has been recognized as a multifunctional cytokine expressed in a wide range of tissues and cells with roles in regulation of wound repair, cell differentiation, apoptosis, embryogenesis, and inflammation. ${ }^{(\mathbf{1})}$

Moreover, a role of activin A has been proposed in several pathological processes such as carcinogenesis and fibrosis, and that cytokine may also be involved in the pathogenesis of 
various inflammatory disorders such as inflammatory bowel disease and rheumatoid arthritis. ${ }^{(3,4)}$ In addition, activin A seems to be involved in atherogenesis by inhibiting foam cell formation and neointimal hyperplasia. ${ }^{(5,6,7)}$ It is widely recognized that inflammatory mechanisms play a pathogenic role in coronary artery disease (CAD). In fact, some researches have suggested that inflammatory mediators play a causal role in several steps involved in the progression of atherosclerosis from local inflammation through plaque formation and rupture. ${ }^{(\mathbf{8}, \mathbf{9}, \mathbf{1 0})}$ However, these inflammatory mediators exert several biologic functions and their relative importance, are not fulfilled.

The activity of activin is regulated by follistatin, a $34-\mathrm{kDa}$ glycoprotein of 288 amino acids which binds activin with high affinity in equimolar complexes that are unable to bind and activate the activin receptors. ${ }^{(11,12)}$

Later it has been reported that follistatin accelerate endocytosis and degradation of activin. ${ }^{(\mathbf{1 3}, \mathbf{1 4})}$

The plasminogen activator (PA) system is an important protective mechanism against stable thrombus formation, two forms of PA have been identified, namely, tissue type plasminogen activator (tPA) and urokinase type plasminogen activator (uPA). ${ }^{(15)} \quad$ Urokinase- type plasminogen activator is a serine protease that activates the zymogen plasminogen, potentially initiating a cascade of fibrinolysis and extracellular proteolysis. ${ }^{(16)}$ Abundant data suggest that uPA may play roles in the vessel wall other than initiating fibrinolysis. (17) It is expressed by endothelial cells and smooth muscle cells in normal human artries. ${ }^{(17)}$ Its expression could contribute to vascular lesion formation by facilitating smooth muscle cell migration and proliferation. ${ }^{(\mathbf{1 8})}$ On the basis that persistant inflammation involves increased levels of inflammatory cytokines that seems to play a pathogenic role in chronic heart failure by influencing heart contractility. The aim of the present work was to assess the role of activin A, follistatin and urokinase- type plasminogen activator in patients with chronic heart failure and to find if there is any correlation among their levels.

\section{SUBJECTS \& METHODS}

The present study was conducted on 30 patients with chronic heart failure as group I and 20 healthy control subjects as group II matched for age and sex.

Chronic heart failure in these patients was developed as a result of dilated cardiomyopathy in $20 \%$ of them (six patients), the rest were the outcome of ischemic heart disease diagnosed by ECG findings. None of the patients had concomitant diseases such as infections, malignancies, autoimmune disorders, diabetes mellitus, hypertensions or chest diseases. All patients and controls were subjected to:

- Thorough history taking.

- Complete clinical examinations.

- Routine investigations.

- Abdominal U/S and x-ray chest.

- ECG. 
- After fasting far more than 12 hours, and while fasting peripheral blood samples were taken for the determination of the following laboratory investigations:

$>$ Lipid profile including serum cholesterol $^{(19)}$, serum triglycerides $^{(20)}$, serum LDL-c and HDL-c by spectrophotometry. ${ }^{(19)}$

- Serum level of both activin $A^{(21)}$ and serum level of follistatin $^{(21)}$ were determined by sandwich- type enzymelinked immunosorbant assay (ELISA).

- Serum urokinase type of plasminogen activator (uPA) by colorimetric method of the chemicon uPA activity assay kit. ${ }^{(22)}$

- Body Mass index for each person of both groups were also calculated by dividing the body weight in $\mathrm{Kg}$ over the height in meters square.

\section{RESULTS}

Body mass index (BMI) and lipid profile for the studied groups are shown in table I, where there was no significant difference between the two studied groups as regard BMI or the serum HDL-c while there was a highly significant difference as regard the rest of lipid profile among the studied groups $(p<0.001)$.

Table II shows the statistical difference between the two groups as regard the studied parameters, serum activin A, serum follistatin and serum urokinase plasminogen activator where there was a highly significant increase in serum activin $A$ and follistatin in group I than group II while a statistical significant decrease was detected as regard serum urokinase plasminogen activator in group I as compared to group II $(\mathrm{p}<0.001)$.

Table III shows the correlation between the studied parameters among the chronic heart failure patients (group I). There was significant positive correlation between Activin $\mathrm{A}$ and urokinase plasminogen activator, follistatin and activin $\mathrm{A}(\mathrm{p}<0.001)$ while there was a significant negative correlation between follistatin and urokinase plasminogen activator $(p<0.05)$.

As regards to the BMI, there was a significant positive correlation with activin A $(\mathrm{p}<0.01)$, also a positive correlation with follistatin and urokinase plasminogen activator was observed $(\mathrm{p}<0.05)$. Lipid profile showed that there was a significant positive correlation between serum total cholesterol, LDL-c and activin A $(\mathrm{p}<0.01)$ while a significant negative correlation was shown with uPA $(p<0.05),(p<0.01)$ respectively.

The LDL fraction showed significant positive correlation with serum cholesterol $(p<0.001)$. While the HDL fraction of lipid profile showed a significant negative correlation with activinA $(\mathrm{p}<0.05)$ and a significant positive correlation with uPA $(\mathrm{p}<0.05)$. A significant negative correlation were with both serum cholesterol and LDL was observed $(\mathrm{p}<0.001)$. 
Table I. body mass index (BMI) and lipid profile for the two studied groups.

\begin{tabular}{|l|l|l|l|l|l|}
\hline $\begin{array}{c}\text { Studied } \\
\text { groups }\end{array}$ & $\begin{array}{c}\text { BMI } \\
\mathbf{k g} / \mathbf{m}^{2}\end{array}$ & $\begin{array}{c}\text { Serum T.G } \\
\mathbf{m g} / \mathbf{d l}\end{array}$ & $\begin{array}{c}\text { Serum } \\
\text { cholesterol } \\
\mathbf{m g} / \mathbf{d l}\end{array}$ & $\begin{array}{c}\text { Serum } \\
\text { LDL-c } \\
\mathbf{m g} / \mathbf{d l}\end{array}$ & $\begin{array}{c}\text { Serum } \\
\text { HDL-c } \\
\mathbf{m g} / \mathbf{d l}\end{array}$ \\
\hline \multirow{2}{*}{ Group I } & 25.697 & 201.0 & 230.4 & 177.3 & 44.6 \\
& \pm 1.348 & \pm 39.448 & \pm 45.503 & \pm 41.382 & \pm 8.633 \\
\hline Group II & 25.205 & 137.65 & 176.7 & 141.9 & 51.2 \\
& \pm 1.460 & \pm 8.75 & \pm 13.436 & \pm 10.867 & \pm 9.833 \\
\hline $\mathrm{P}$ & $>0.05$ & $<0.001$ & $<0.001$ & $<0.001$ & $>0.05$ \\
\hline
\end{tabular}

Table II. Serum levels of Activin A (ng/ml), Follistatin (pg/ml) and Urokinase plasminogen activator (IU/ ml) of the two studied groups

\begin{tabular}{|l|c|c|c|}
\hline $\begin{array}{c}\text { Studied } \\
\text { groups }\end{array}$ & $\begin{array}{c}\text { Activin A } \\
\text { (ng/ml) }\end{array}$ & Follistatin (pg/ml) & $\begin{array}{c}\text { Urokinase Plasminogen } \\
\text { activator (IU/ml) }\end{array}$ \\
\hline Group I & $8.007 \pm 2.877$ & $2086.563 \pm 768.930$ & $1.457 \pm 0.546$ \\
\hline Group II & $2.725 \pm 0.433$ & $1361.985 \pm 464.255$ & $3.975 \pm 1.268$ \\
\hline P & $<0.001$ & $<0.001$ & $<0.001$ \\
\hline
\end{tabular}

Table III Correrlation between the studied parameters among the chronic heart failure patients (group I)

\begin{tabular}{|l|c|c|l|l|l|l|l|}
\hline & Activin A & Follistatin & uPA & BMI & $\begin{array}{l}\text { Serum } \\
\text { T.G }\end{array}$ & $\begin{array}{l}\text { Serum total } \\
\text { cholesterol }\end{array}$ & $\begin{array}{l}\text { Serum } \\
\text { LDL-c }\end{array}$ \\
\hline Follistatin & $0.770^{* * *}$ & & & & & & \\
\hline uPA & $0.650^{* * *}$ & $-0.418^{*}$ & & & & & \\
\hline BMI & $0.510^{* *}$ & $0.410^{*}$ & $0.359^{*}$ & & & & \\
\hline Serum T.G & $0.420^{*}$ & 0.081 & $-0.410^{*}$ & $0.510^{* *}$ & & & \\
\hline $\begin{array}{l}\text { Serum total } \\
\text { cholesterol }\end{array}$ & $0.450^{* *}$ & 0.020 & $-0.440^{*}$ & $0.480^{* *}$ & 0.181 & & \\
\hline Serum LDL-c & $0.450^{* *}$ & 0.028 & $-0.480^{* *}$ & $0.550^{* *}$ & 0.060 & $0.692^{* * *}$ & \\
\hline Serum HDL-c & $-0.440^{*}$ & 0.059 & $0.390^{*}$ & -0.006 & -0.268 & $-0.591^{* * *}$ & $-0.565^{* * *}$ \\
\hline
\end{tabular}

Data are presented as $r$ (correlation coefficient)

*Significant at the 0.05 level (2-tailed)

**Significant at the 0.01 level(2-tailed)

***Significant at the 0.001 level (2-tailed) 


\section{DISCUSSION}

A growing body of evidence links inflammation to the pathogenesis of heart failure. On the basis of its potential role in inflammation, fibrosis and wound repair - activin A was thought that it might be involved in the pathogenesis of heart failure. ${ }^{(23,24)}$

In the current study, heart failure patients had markedly elevated serum level of activin A compared to healthy control subjects, a finding which might suggest a pathogenic role for activin $\mathrm{A}$ in the development of heart failure.

Such finding is in agreement with the result of Yndestad et al. ${ }^{(23)}$ who found high levels of activin A in heart failure patients with high levels according to disease severity. ${ }^{(23)}$ They suggested that, the failing myocarduim itself may contribute to the enhanced activin A levels during heart failure with cardiomyocytes as the primary cellular source. ${ }^{(23)}$ Also, Smith et al. ${ }^{(25)}$ al have reported high levels of activin $\mathrm{A}$ as assessed by protein serum level and m RNA levels in PMNCs in patients with stable angina than healthy controls, they suggested that activin A promote plaque stabilization by inhibiting foam cell formation and by inducing a contractile non-proliferative phenotype in cultured smooth muscle cells. ${ }^{(25)}$

Waard et al. ${ }^{(26)}$ found that activin $A$ is a potent inducer of cardiac ankyrin repeat protein expression in smooth muscle cells which play a key role during atherosclerosis. ${ }^{(7,26)}$

Engelse and his colleagues ${ }^{(6)}$ experiments revealed the presence of activin A in normal media of blood vessels with a higher level of expression in the atherosclerotic vessels. They also found that follistatin was expressed at similar levels to that of activin $\mathrm{A}^{\left({ }^{(6)}\right.}$

Their findings concerning follistatin are coinciding with the present findings that there is high follistatin level in heart failure patients as compared to the controls.

Although Smith et al., (25) found no significant difference in plasma levels of follistatin between patients with stable and unstable angina as compared to the control group as well as its gene expression among the three groups. ${ }^{\text {(25) }}$

The results of the present study showed a significant decrease in serum level of uPA among the heart failure patients than the normal control group. Such finding is coinciding with the fact that plasminogen activation system is an important protective mechanism against thrombus formation as it is responsible for breakdown of plasminogen into plasmin which is able to breakdown the fibrin polymer of blood clots. ${ }^{(27,28)}$

Ljungner and Bergqvist, ${ }^{(29)}$ have demonstrated diminished plasminogen activation activity in atherosclerotic compared with normal blood vessels. ${ }^{(29)}$

Bjorkerud $^{(30)}$ has characterized the expression of the overall fibrinolytic capacity of cultured vascular smooth muscle cells from normal media and atherosclerotic intima and suggested that impaired fibrinolytic capacity existed from the later source. $^{(30)}$ 
Raghunath et al. ${ }^{(28)}$ showed that altered expression of plasminogen activator system components may predispose to thrombosis as they found by immuno histochemistry that the degree of staining showed the following order PAI.1 $>$ tPA $>$ uPAR $>$ UPA either in fibrointimal proliferative human coronary arteries or those who developed atherosclerotic plaques. ${ }^{(28)}$ In other investigations it was found that uPA deficient mice have marked fibrin deposition and shortened life span. ${ }^{(31)}$

Labarrere et al. ${ }^{(32)}$ concluded that depletion of tPA from vascular smooth muscle cells is accompanied by the loss of antithrombin natural anticoagulant pathway from arteries and arterioles and considered as early sign of the development of coronary artery disease. $^{(32)}$

Bochaton-Piallat et al. ${ }^{(33)}$ demonstrated that uPA increases in cultured smooth muscle cell from intimal thickening 15 days after endothelial injury. ${ }^{(33)}$ As proved by other investigators who showed that both UPA and its receptors have been detected in human atherosclerotic lesions. ${ }^{(34)}$

Carmeliet and colleagues ${ }^{(35)}$ have demonstrated that neointimal formation is reduced in uPA deficient mice suggesting its role in that process. $^{(35)}$

The current results showed a positive significant correlation between activin $A$ and uPA suggesting a possible role of the former cytokine in fibrinolytic activity of uPA. Bochaton-Piallat et al. ${ }^{(33)}$ showed that TGF-B generally didn't affect uPA activity in smooth muscle cell type but surprisingly only to spindle clones exhibited an increase in uPA activity in response to TGF- $\beta$, that finding indicated that the effects of TGF-B depend on several parameters. ${ }^{(33)}$

Generation of plasmin can activate TGF-B release that are autocrinally regulate the cell growth in vessel walls. ${ }^{(34)}$

Also, there was a significant negative correlation between uPA ,serum total cholesterol and serum LDL-c which can be explained by the work of Zhang and his colleagues who showed that although uPA was involved in the release and disaggregation of LDL in macrophages as the resulted plasmin is protected from the action of the serum inhibitors, it doesn $t$ cause degradation of native (monomeric) LDL owing to limited expression of LDL receptor on macrophages. ${ }^{(36)}$

A positive significant correlation was noticed in the present study between UPA and HDL-c. However, some investigators suggested that over expression of Apo A in mice (a component of HDL) increases susceptibility to diet-induced atherosclerosis by decreasing cellassociated plasminogen activation of the vessel wall. ${ }^{(28)}$

A positive significant correlation was observed between serum activin and both serum cholesterol and serum T.G. kozaki et al. ${ }^{(5)}$ who treated macrophages with activin $\mathrm{A}$ and found a dose dependant decrease in cholesterol ester accumulation which was paralleled by a reduction in cell association and degradation of acetylated LDL-c. Results of follistatin showed an opposite effect. ${ }^{(5)}$ 
In conclusion, the present study could suggest the possible pathogenic role of activin $\mathrm{A} /$ follistatin system in the development of heart failure as well as the role of urokinase plasminogen activator in the pathogenesis of atherosclerosis that predisposes to heart failure. Further investigations are needed to identify the role of different cytokines and fibrinolytic system in the progression of atherosclerosis and myocardial failure

\section{REFERENCES}

1. Chen YG, Lui HM, Lin SL, Lee JM and Ying SY (2002): Regulation of cell proliferation, apoptosis, and carcinogenesis by activin. Exp Biol Med (May wood)., 227:75-87.

2. Chen YG, Wang Q, Lin SL, Chang CD, Chung $J$ and Ying SY (2006): Activin signaling and its role in regulation of cell proliferation, Apoptosis and carcinogenesis. Exp Biol Med., 231:534- 44.

3. Phillips DJ, Jones KL, Scheerlinck JY, Hedger MP and de Krestser DM (2001): Evidence for activin $\mathrm{A}$ and follistatin involvement in the systemic inflammatory response. Mol Cell Endocrinol., 180: 15562.

4. Gribi R, Tanaka T, HarperSummers $R$ and YuJ (2001): Expression of activin $A$ in inflammatory arthropathies. Mol CellEndocrinol., 180: 163-7.

5. Kozaki K, Akishita M, Eto M,Toba K, Inone S, Ishikawa M, Hashimoto M, Kodama
T,Yamada N,Orimo $H$ and Ouchi Y (1997): Role of activin$A$ and follistatin in foam cell formation of THP-1 macrophages. Arterioscler Thromb Vasc Biol., 17: 2389-94.

6. Engelse MA, Neele JM, van Achterberg TA, Van A Ken BE, Van Schaik RN, Panne Koek H and Vries CM (1999): Human activin-A is expressed in the atherosclerotic lesion and promotes the contractile phenotype of smooth muscle cells. Circ Res. ,85:931-9.

7. Engelse MA, Lardenoye JHP, Neele JM, Grimbergen JM, Vries Mr, Lamfers MM,Panne Koek H, Quax PA and Vries CM (2002): Adenoviral activin A expression prevents intimal hyperplasia in human and murine blood vessels by maintaining the contractile smooth muscle cell phenotype. Circ Res., 90:112834.

8. Ross R (1999): Atherosclerosisan inflammatory disease. N Engl J Med., 340: 115-26.

9. Hansson G.K, Libby P., Schönbeck U. and Yan Z.O (2002): Innate and adaptive immunity in the pathogensis of atherosclerosis. Circ Res., 91: 281-91.

10. Libby $P$ and. Aikawa $M$ (2002): Stabilization of atherosclerotic plaques: New mechanisms and clinical targets. Nat Med., 8: 1257-62.

11. Ueno N, Ling N, Ying SY, Esch F, Shimasaki S, Guillemin R(1987): Isolation and partial characterization of follistatin: a single-chain $\quad \mathrm{Mr} \quad 35,000$ 
monomeric protein that inhibits the release of FSH. Proc Natl Acad Sci (U S A). 84: 8282-6.

12. de Winter $J P$, ten Dijke $P$, de Vries CJ, van Achterberg TA, Sugino $H$, de Waele $P$, Huylebroeck D, Verschueren Kk, van den Eijnden-van Raaij AJ (1996): Follistatins neutralize activin bioactivity by inhibition of activin binding to its type II receptors. Mol Cell Endocrinol., 116:105-14.

13. Sidist Y, Schneyer A, Slusst P, Johnson $L$ and Keutmann $H$ (2001): Follistatin: 2J. Biol. Chem., 276(21): 17718-26.

14. Kuetmann $H$, Schneyer $A$ and Sidis Y (2004): The role of follistatin domains in follistatin biological action. Mol.Endocrinol., 18(1) : 228-40.

15. Kristensen $P$, Larsson L-I, Nielsen LS, Grndahl-Hansen J, Andreasen PA, Dan K1984): Human endothelial cells contain one type of plasminogen activator. FEBS (Lett.) 168:33-7.

16. Bachmann F (2001): Hemostasis and Thrombosis in: Basic Principles and Clinical Practice, eds. Colman, R. W., Hirsh, J., Marder, V.J., Clowes, A. W. \& George, J. N. (Lippincott, Philadelphia)pp., 275-320.

17. Kienast J., Pardo T., Steins M., Li C. X., Schmid, K. W., Hammel D., Scheld H. H. and van de Loo J C (1998): Relation of urokinase-type plasminogen activator expration to presence and severity of atherosclerotic lesion in human coronary arteries. Thromb. Haemostasis 79: 579-86.
18. Clowes, A. W., Clowes, M. M., Au, Y. P. T., Reidy, M. A. and Belin, D (1990): Smooth muscle cells express urokinase during mitogenesis and tissue-type plasminogen activator during migration in injured rat carotid artery.Circ. Res., 67: 61-7.

19. Richmond W (1973): Total cholesterol determination by CHOD, PAP method. Klin Chem Klin Biochem., 12: 226.

20. Mc Gowan M.W (1983): Enzymatic, liquid, colourimetric test for triglyceride determination. Clin Chem., 29: 538.

21. Valderrama-carrajal, Cocolakis E, Lacerte A, Lee EH, Krystal G, Alu S and Leberun JJ (2002): Activin/TGF-beta induces apoptosis through $\mathrm{S}$ maddependant expression of the lipid phosphatase SHIP. Nat Cell Biol., 4(12): 963-9.

22. Nuria A P, Florian $S$ and Eva $K$ S (2002): Interaction of plasminogen activator inhibitor type-1(PA-1) with vitronectin. Eur.J.Biol.Chem., 269:184-92.

23. Yndestad A, Ueland T, øie E, Florholme G, Halvorsen B, Attramadal $\mathbf{H}$, Simonsen $\mathrm{S}$, Frøland S, Gullestad L, Christensen G, Damås $\mathrm{J}$ and Aukrust P (2004): Elevated levels of activin $A$ in heart failure. Circulation 109:1379-85.

24. Aukrust P, Gullestad L, Ueland T, Damås $J$ and Yndestad $A$ (2005): Inflammatory and antiinflammatory cytokines in chronic heart failure: Potential theraimplications. Annals of Med., 37(2):74-85. 
25. Smith C, Yndestad A, Halvorsen B, Ueland T, Wæhre T, Otterdal K, Scholz $\mathbf{H}$, Endersen K, Gullestad L, Frøland S, Damås $J$ and Aukrust P (2004): Potential antiinflammatory role of activin $\mathrm{A}$ in acute coronary syndromes. J. Am. Collage Cardiol., 44 (2): 369-75.

26. Waard V, Achterberg $T$, Beauchamp N, Pannekoek $\mathbf{H}$ and de Vries C (2003): Cardiacankyrin repeat protein (CARP) expression in human and murine atherosclerotic lesions. Arterioscler Thromb Vasc Biol., 23:64.

27. Hansen H, Petros A, Meadows R, Nettescheim D, Mazar A, Olejniczak K, Xu R, PedersonT, Henkin $\mathrm{J}$ and Fesik $S$ (1994): Solution structure of the amino terminal fragmen of urokinase-type Plasminogen activator. Biochemistry 33:4847.

28. Raghunath P,Tomaszewski J, Brady S, Caron S, Okada S and Barnathan E (1995): Plasminogen activator system in human coronary atherosclerosis. Arterioscler Thromb Vas Biol., 15:1432-43.

29. Ljungner $H$, Bergqvist $D$ (1984): Decreased fibrinolytic activity in human atherosclerotic vessels. Atherosclerosis 50:113-6.

30. Bjorkerud S (1988): Impaired fibrinolysis-inducing capacity for post injury phenotype of cultivated human atherosclerotic intimal smooth muscle cells. Circ Res., 62:1011-8.

31. Carmeliet $\mathbf{P}$, Schoonjans L, Kieckens L, Ream B, Degen J,
Bronson R, deVos R, Vanden OJ, Collen $D$ and Mulligan $R$ (1994): Physiological consequences of loss of plasminogen activator gene function in mice. Nature 368:41924.

32. Labarrere C, Petts D, Nelson D and Faulk W (1995): Vascular tissue plasminogen activator and the development of coronary artery disease in heart-transplant recipients. N Eng J Med., 333(17):1111-6.

33. Bochaton-Piallat $M$, Gabbiani $G$ and Pepper $M$ (1998): Plasminogen activator expression in rat arterial smooth muscle cells depends on their phenotype and is modulated by cytokines. Cir Res., 82: 1086-93.

34. Ellis V and Whawell S (1997): Vascular smooth muscle cells potentiate plasmin generation by both urokinase plasminogen activator-dependant mechanisms: Evidence for a specific tissuetype plasminogen activator receptor on these cells. Blood 90(6): 2312-22.

35. Carmeliet P, Moons L, Herbert J-M, Crawley J, Iupu F Ljinen $R$ and Collen $D$ (1997): Urokinase but not tissue plasminogen activator mediates arterial neointimal formation in mice. Cir Res., 81: 829-39.

36. Zhang $W$, Ishii $I$ and Kruth $H$ (2000): Plasminogen-mediated macrophage reversal of low density lipoprotein aggregation. J Biol.Chem., 275(42): 33176-83. 


\section{مستوى الأكتيفين A والفوليستاتين في حالات هبوط القلب المزمن}

$$
\begin{aligned}
& \text { هويدا نونو؛ عَزّة حسن "*؛ حنان كمال عبد العزيز } \\
& \text { قسمى الكيمياء الحيويةِ والأمراض الباطنة } \\
& \text { كليّة الطبِّ، جامعة الأسكندرية، مصر }
\end{aligned}
$$

أكتيفين A عضو في عائلة عامل النمو التحولى - بيتا له دور فى عدة أمراض. منها مرض تصلب

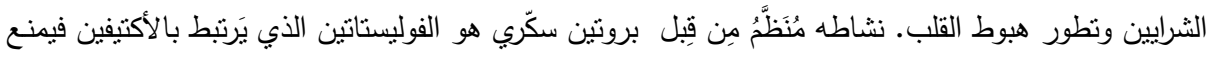

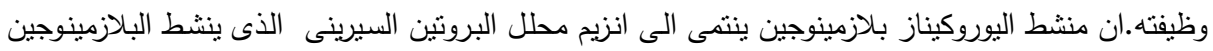
وبالتالى يبدأ عملية متتابعة لتحليل الألياف وتحليل البروتينات خارج الخلية.

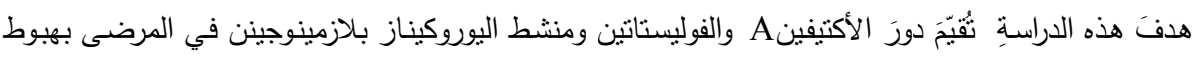
القلب المُزمنِ والعلاقة بينهم.

أجريت هذه الدراسـة على · ب مريض بهبوط القلب المزمن كنتيجة لاعتلال عضلـة القلب أو اسكيميا

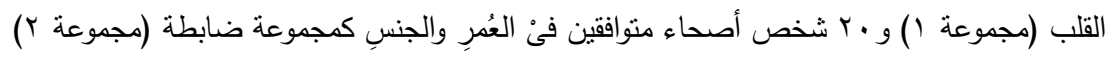

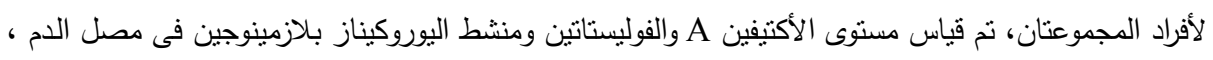

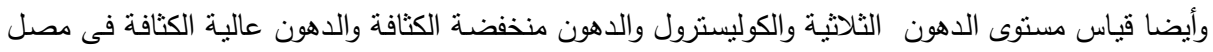

النتَائج: أظهرت زيادة ذ ات دلالة احصـائية فى مستوى الأكتيفين A والفوليستاتين فى مصل الدم

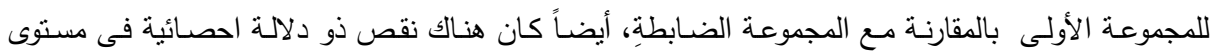
منشط اليوروكيناز بلازمينوجين فى المرضى مقارنة بالمجموعة الضابطة بالنسبة لمستوى الدهون وجدت زيادة

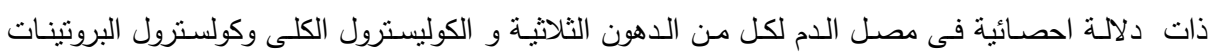

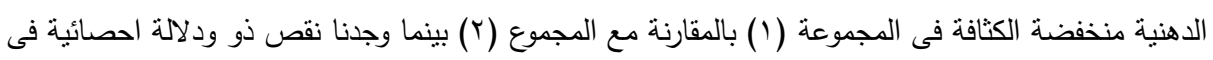

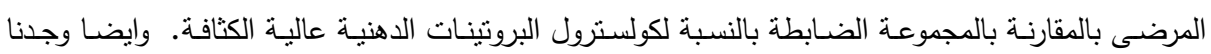

علاقة ارتباط احصائيه موجبه بين مسنوى الأكتيفينA و و اليوروكيناز بلازمينوجين فى المجموعة الاولى.

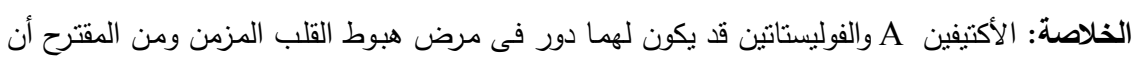

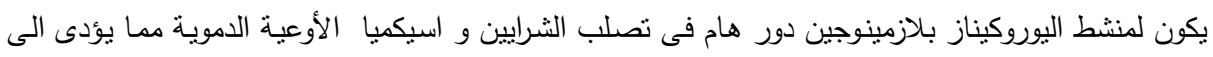
هبوط القلب. من الممكن ان يكون للأكتيفين A دور فى نشاط تحليل الالياف لمنشط اليوروكيناز بلازمينوجين. 